This is an electronic reprint of the original article. This reprint may differ from the original in pagination and typographic detail.

Author(s): $\begin{aligned} & \text { Karttunen, Jenni; Mäntynen, Sari; Ihalainen, Teemu; Lehtivuori, Heli; Tkachenko, } \\ & \text { Nikolai; Vihinen-Ranta, Maija; Ihalainen, Janne; Bamford, Jaana; Oksanen, Hanna }\end{aligned}$

Title: $\quad$ Subcellular localization of bacteriophage PRD1 proteins in Escherichia coli

Year: $\quad 2014$

Version:

Please cite the original version:

Karttunen, J., Mäntynen, S., Ihalainen, T., Lehtivuori, H., Tkachenko, N., VihinenRanta, M., Ihalainen, J., Bamford, J., \& Oksanen, H. (2014). Subcellular localization of bacteriophage PRD1 proteins in Escherichia coli. Virus Research, 179 (2014)(22), 4452. https://doi.org/10.1016/j.virusres.2013.11.015

All material supplied via JYX is protected by copyright and other intellectual property rights, and duplication or sale of all or part of any of the repository collections is not permitted, except that material may be duplicated by you for your research use or educational purposes in electronic or print form. You must obtain permission for any other use. Electronic or print copies may not be offered, whether for sale or otherwise to anyone who is not an authorised user. 


\title{
Subcellular localization of bacteriophage PRD1 proteins in Escherichia coli
}

\author{
Jenni Karttunena, Sari Mäntynena, Teemu O. Ihalainen ${ }^{b}$, Heli Lehtivuorib, Nikolai V. \\ Tkachenkoc, Maija Vihinen-Ranta $^{b}$, Janne A. Ihalainen' ${ }^{b}$, Jaana K.H. Bamforda, Hanna M. \\ Oksanen ${ }^{\mathrm{d}}$,
}

Virus Research 179 (2014) 44-52

a Centre of Excellence in Biological Interactions, Department of Biological and Environmental Science and Nanoscience Center, P.O. Box 35, 40014 University

of Jyväskylä, Finland

b Nanoscience Center, Department of Biological and Environmental Science, P.O. Box 35, 40014 University of Jyväskylä, Finland

c Department of Chemistry and Bioengineering, Tampere University of Technology, P.O. Box 541, 33101 Tampere, Finland

d Institute of Biotechnology and Department of Biosciences, P.O. Box 56, 00014 University of Helsinki, Finland

Keywords: Membrane virus; Confocal microscopy; Protein interactions; Virus assembly; Bacteria

\begin{abstract}
Bacteria possess an intricate internal organization resembling that of the eukaryotes. The complexity is especially prominent at the bacterial cell poles, which are also known to be the preferable sites for some bacteriophages to infect. Bacteriophage PRD1 is a well-known model serving as an ideal system to study structures and functions of icosahedral internal membrane-containing viruses. Our aim was to analyze the localization and interactions of individual PRD1 proteins in its native host Escherichia coli. This was accomplished by constructing a vector library for production of fluorescent fusion proteins. Analysis of solubility and multimericity of the fusion proteins, as well as their localization in living cells by confocal microscopy, indicated that multimeric PRD1 proteins were prone to localize in the cell poles. Furthermore, PRD1 spike complex proteins P5 and P31, as fusion proteins, were shown to be functional in the virion assembly. In addition, they were shown to co-localize in the specific polar area of the cells, which might have a role in the multimerization and formation of viral protein complexes.
\end{abstract}




\section{Introduction}

Bacterial cells have been mainly regarded as amorphous reaction vessels concealing a homogenous solution of proteins. Due to advances in bacterial cell biology, this traditional view has changed dramatically. Similarly to eukaryotes, bacteria deploy macromolecules such as proteins, lipids and nucleic acids into specific subcellular locations. This asymmetric architecture is spatially and temporally dynamic, enabling cells to respond to changing demands during their life cycle (Rudner and Losick, 2010). Accumulated data on bacterial proteins have revealed a variety of localization patterns (Amster-Choder, 2011). Whereas certain proteins oscillate from pole to pole (Gerdes et al., 2010, Leonardy et al., 2010 and Loose et al., 2011), others form clusters on the bacterial cell surface or at specific sub-cellular locations (Amster-Choder, 2011). In addition, it is known that certain bacterial proteins, especially cytoskeletal, assemble into helical structures extending along the cell or construct ring-like structures at the mid-cell position (Vats et al., 2009). However, interpretation of the localization pattern data with fluorescent tagged proteins has been challenging and some artifacts have emerged (Swulius and Jensen, 2012).

Recent studies have elucidated factors governing the asymmetric protein distribution in bacteria, which is presumably most commonly mediated by 'diffusion and capture', when proteins diffuse freely until interacting with other, so-called target proteins (Deich et al., 2004 and Rudner and Losick, 2002). This raises the question about the primary factors directing the target proteins to their specific cellular sites, and emphasizes the need to reveal other mechanisms for protein targeting. For instance, self-assembly is a unique variation of the 'diffusion and capture' positioning, which does not require any preexisting anchor structures. Cellular factors such as geometric cues and physical constrictions have a role in positioning a number of bacterial proteins into their specific intracellular sites (Rudner and Losick, 2010). Also localization signals can be found in certain bacterial proteins, similarly to their eukaryotic analogs (Russell and Keiler, 2007). Correspondingly, there is evidence of subcellular localization of certain mRNA transcripts correlating with the localization of their protein products (Nevo-Dinur et al., 2011). Yet another mechanism for protein positioning was brought up by the discovery of cytoskeletal proteins in bacteria (Vats et al., 2009). These structures are also suggested to provide a track for other proteins to locate, resembling again the situation in eukaryotes (Nevo-Dinur et al., 2012). However, the underlying principles of targeting for most bacterial proteins remain elusive.

The studies indicate that the asymmetric protein distribution is particularly conspicuous at the chemically and physically unique cell poles (Lai et al., 2004). For instance, unequally distributed lipid composition and negative curvature of the membrane (Ramamurthi, 2010) are believed to contribute to encompassing proteins into these cellular areas (Nevo-Dinur et al., 2012). It has also been shown that a number of bacteriophages infect preferably at these extreme regions. These viruses bind to distinct cellular receptors on the surface of their Gram negative hosts such as Escherichia coli, Yersinia pseudotuberculosis, or Vibrio cholera (Edgar et al., 2008 and Rothenberg et al., 2011) or Gram positive ones such as Bacillus subtilis (Jakutyte et al., 2011). This implies that the cell poles contain cellular components essential for DNA intake (Edgar et al., 2008). The hypothesis is supported by the fact that the poles are the preferred site of DNA intake in 
natural competent cells (Chen et al., 2005 and Edgar et al., 2008). Moreover, in studies of B. subtilis infecting phage SPP1 (Jakutyte et al., 2011) and E. coli phage lambda (Rothenberg et al., 2011) it was observed that in addition to being injected, viral DNA is replicated at the poles. However, several proteins of replication machinery of bacteriophage $\phi 29$ infecting B. subtilis have been found localized in helix-like pattern near the membrane. It was also shown that the $\phi 29$ replication is dependent on cytoskeleton protein MreB, as also with phage PRD1 (Muñoz-Espín et al., 2009). Terminal protein of these phages has been shown to associate with bacterial nucleoid independently of other phage-coded proteins as well as localize in the nucleus of mammalian cells (Muñoz-Espín et al., 2010 and RedrejoRodriguez et al., 2012). It seems that bacteriophages have evolved to exploit the internal asymmetry of their host cells in order to make the infection process more efficient.

One of the most extensively studied bacteriophages is Enterobacteria phage PRD1 (family: Tectiviridae, genus: Tectivirus), which infects various Gram negative bacteria, such as E. coli and Salmonella typhimurium, carrying P-, W- or N-type conjugative plasmid, whereas other tectiviruses can also infect Gram positive bacteria such as Bacillus (Grahn et al., 2006 and Oksanen and Bamford, 2012). The PRD1 virion is formed by an icosahedral protein capsid surrounding a protein-rich membrane which, in turn, encloses the linear dsDNA genome ( Abrescia et al., 2004, Cockburn et al., 2004 and Olsen et al., 1974). Based on X-ray crystallographic analyses, PRD1 belongs to a certain structure based viral lineage with several other viruses such as: adenovirus, Paramecium bursaria chlorella virus 1 (PBCV-1) and Sulfolobus turreted icosahedral virus (STIV) ( Abrescia et al., 2012, Benson et al., 1999, Khayat et al., 2005 and Nandhagopal et al., 2002). All these viruses have a major capsid protein with a double $\beta$-barrel fold and similar virion architecture. In PRD1, the capsid is mainly composed of the major capsid protein P3, which forms pseudohexameric trimers (Abrescia et al., 2004 and Benson et al., 1999). The receptor binding spike complex at the virion vertices contains the pentameric penton protein P31 forming the base structure from which the trimeric spike protein P5 and the monomeric receptor binding protein P2 protrude ( Caldentey et al., 2000, Merckel et al., 2005, Rydman et al., 1999 and $\mathrm{Xu}$ et al., 2003). The spike structure complex is stabilized by the integral membrane protein P16 linking the vertex to the underlying viral membrane (Jaatinen et al., 2004). In addition to several other PRD1 structural proteins, also a number of nonstructural proteins have been identified, such as the tetrameric assembly protein P17 required for virion formation (Caldentey et al., 1999, Holopainen et al., 2000 and Mindich et al., 1982). Despite the intensive structural and functional characterization, the interactions of a number of predicted PRD1 proteins are yet to be revealed.

Our aim was to analyze the localization and interactions of PRD1 proteins in its native host bacterium E. coli. The study included viral monomeric and multimeric structural proteins, an integral membrane protein and a soluble assembly protein. Special attention was paid to the receptor binding spike complex proteins P5 and P31 for which the structures at atomic resolution are known (Abrescia et al., 2004, Caldentey et al., 2000 and Rydman et al., 1999). We localized the proteins in living cells by exploiting fluorescent fusion protein technology and confocal microscopy. 


\section{Results and discussion}

\subsection{Construction of bacterial expression vector library to produce fluorescent fusion proteins}

We created a bacterial vector library for convenient production of fluorescent fusion proteins (Fig. 1; Table 1). The vectors were constructed by cloning genes encoding eGFP and its cyan and yellow variants eCFP and eYFP. We used two bacterial vectors pSU18 and pET24 bearing replicons p15A and ColE1, respectively, enabling simultaneous expression of two proteins. According to confocal microscopy the expression of the fluorescent protein genes in bacterial cells produced functional proteins (for eYFP see Section 2.3, for eGFP and eCFP data not shown). Using these vectors, it is possible to insert any gene of interest into either end of the fluorescent protein gene, thereby creating $\mathrm{N}$ terminal fluorescent fusion protein (the fluorescent protein is linked to the N-terminus of the target protein) or C-terminal fluorescent fusion protein (the fluorescent protein is linked to the C-terminus of the protein). A linker sequence of six glycines was designed to these vectors to separate the fluorescent protein from the protein of interest reducing steric hindrance. In this study, we exploited the vector library to create cyan and/or yellow fluorescent fusion proteins of bacteriophage PRD1 proteins P2 (receptor binding protein), P3 (major capsid protein), P5 (spike protein), P16 (vertex stabilizing integral membrane protein), P17 (non-structural assembly protein), and P31 (penton protein) (Table 1). Genes were cloned into both vector types (Fig. 1) using either pSU18 or pET24 to produce both N-terminal and C-terminal fusion proteins, except gene XVII, for which only fusion P17eYFP was available. Sequencing of the vectors revealed only minor changes in PRD1 genes (Supplementary Table S1).

\subsection{Solubility and multimericity of viral fluorescent fusion proteins}

In the fusion protein studies, the first concern is whether the fusion affects on the folding and functionality of the native protein. One way to evaluate this is to monitor changes in the protein solubility and find out whether the known multimeric proteins form multimers with fluorescent protein tags. The majority of the fusion proteins (P2, P3, P5, P17 and P31) were expressed as soluble (data not shown). These proteins were directed to sedimentation assay by a rate zonal centrifugation for the size determination.

Monomeric receptor binding protein P2 (Grahn et al., 1999 and Xu et al., 2003) was expressed as a fusion protein in a monomeric form (Fig. 2A). Small fraction of smaller side-product was detected with both P2 fusions. More variation in the molecular mass distribution was detected with proteins, which can be released as multimers from the virion. The individual PRD1 spikes composed of the trimeric protein P5 form an elongated structure (Bamford and Bamford, 2000, Caldentey et al., 2000, Huiskonen et al., 2007 and Merckel et al., 2005), and there is no obvious reason that the fluorescent tag at the Cterminus of the protein would interfere the folding. The N-terminal fusion protein eYFPP5 ( 61 kDa) sedimented as a monomer (Fig. 2B), but also a smaller multimeric side product $(\sim 45 \mathrm{kDa})$ was detected by an antibody against P5 (data not shown). The Cterminal fusion protein P5-eYFP showed two separate peaks in the sedimentation assay indicating that the protein was in two different forms (monomer and multimer) (Fig. 2B). 
It also had a smaller P5-specific side-product ( $55 \mathrm{kDa})$ in fractions representing monomeric and multimeric proteins (data not shown). The rate zonal centrifugation indicated that the C-terminal fusion of the penton protein P31 was mainly monomeric whereas the fluorescent protein attached to the N-terminus of P31 formed larger multimers (Fig. 2C). This correlates well with the known P31 X-ray structure as its Ctermini are located in the middle of the pentamer (Abrescia et al., 2004) and therefore the added fluorescent tag can hinder the formation of the multimeric complex. However, the N-termini of P31 are pointing outwards from the pentamer (Abrescia et al., 2004). Thus, the N-terminal fluorescence tag should not interfere with the formation of the multimer.

Both fluorescent protein fusions with the major capsid protein P3 were broadly distributed in the multimericity assay starting from the monomeric forms, but also trimeric molecules were detected (P3 is a trimer; Benson et al., 1999) (Fig. 2D). Sedimentation analysis of the assembly protein P17 fusion (P17-eYFP) revealed both monomeric and multimeric forms (Fig. 2E).

The functionality of the produced fluorescent fusion proteins P5 and P31 was tested by complementation assay using PRD1 virus mutants, sus690 and sus525, having amber mutation either in gene $V$ (protein P5) or gene XXXI (protein P31), respectively. Both Nand C-terminal versions of P5 and P31 fusion proteins complemented the defect in the corresponding gene at the same level as with the plasmid-produced wt protein or when the mutant was grown on suppressor host (Table 2) showing that the folding of the proteins was not compromised. According to the results fluorescent fusions did not seem to interfere the viral proteins significantly and multimerization was altered mostly in cases where the protein structures suggested steric hindrance between protein subunits.

\subsection{Multimeric PRD1 proteins localize in the cell poles of E. coli}

Localization of the fluorescent fusion proteins in E. coli cells was studied by confocal microscopy using living cells at the stationary phase of the bacterial growth. As a fusion protein, P16 was expressed all over the cytoplasm ( Fig. 3A and B). Localization around the circumference of the cells, which is typical for membrane proteins, was not observed (Li and Young, 2012 and Maier et al., 2008). In the virion, protein P16 locks the vertex complex to the inner membrane stabilizing the vertex structure and is found in the virus membrane (Abrescia et al., 2004 and Jaatinen et al., 2004). During virus assembly, the interaction of P16 with the virus membrane might require other viral proteins, which may explain the localization of the P16 fusion protein. It is known that the formation of the procapsid including also P16 is dependent on the non-structural scaffolding protein P10 and assembly factor(s) P17 (and most probably P33) (Bamford et al., 2002, Mindich et al., 1982 and Rydman et al., 2001).

Although both fusions of the monomeric receptor binding protein P2 were also evenly distributed inside the bacterium, P2 was occasionally found specifically localized in the cell poles (Fig. 3C and D). Clear loci (a locus is used here to describe the specific localization of fluorescence in a cell) were detected mainly with multimeric fusion proteins, especially with the spike protein P5 (Fig. 3E and F). Both fusions were clearly localized in one specific polar locus in the majority of the cells ( $64 \%$ and $\sim 81 \%$; Fig. $3 \mathrm{E}$ and F). 
More notable variations between $\mathrm{C}$ - and N-terminal fusion proteins were detected with the penton protein P31 and the major capsid protein P3. Like P2 fusion proteins, the fluorescence of P31-eYFP was evenly spread in the cytoplasm in the most of the cells, but about $5 \%$ of the cells had specific fluorescence locus (Fig. 3G). Most of the cells producing eYFP-P31 ( 90\%) had very low intensity level and the fluorescence was spread throughout the cytoplasm (Fig. $3 \mathrm{H})$. However, rest of the cells $(\sim 10 \%)$ were having high fluorescence intensity and eYFP-P31 was specifically localized in the polar end of the bacteria (Fig. $3 \mathrm{H})$. It can be concluded that the multimeric P31 fusion proteins were found mostly localized in specific polar regions more frequently than the monomeric ones (Fig. 2 and Fig. 3).

The C-terminal fusion of the major capsid protein P3 (P3-eYFP) formed clear polar loci in half of the analyzed cells in all cultivations (Fig. 3I). With the eYFP-P3 fusion protein, the specific localization was detected only in around half of the parallel cultures. The other half of the cultivations had cells with fluorescence equally distributed. The parallel samples used for data collection on eYFP-P3 (Fig. 3J) were taken from the cultures with clear localization. Specific loci were detected not only in the polar region, but eYFPP3 was also found specifically localized in several other regions inside the cell $(\sim 69 \%$ of the cells had loci) (Fig. 3J). Fluorescence was also found in specific loci in the fusion of assembly protein P17 (P17-eYFP) on most of the cells (Fig. 3K). P17 is tetrameric (Caldentey et al., 1999), but its function in the virus assembly is rather unknown. As a control, eYFP was produced alone and it was distributed evenly across the bacterial cell, as also previously reported (Fig. 3L) (Deich et al., 2004 and Edgar et al., 2008).

The amount of loci in one cell was calculated from the samples, in which $\sim 10 \%$ or more of the cells were with loci (Fig. 4). Protein P31 and most of the protein P5 were localized in one specific locus. The remaining cells producing P5 had two loci. With P17eYFP the number of loci in one cell was slightly more diverse (from one to five loci), but majority of the cells had one locus (60\% of cells with localization). Both P3 fusion proteins were often found in several specific positions (Fig. 4). Especially, eYFP-P3 was localized more often in three or more loci per cell than in one specific locus. In the virion, the major capsid protein P3 has a connection to the viral inner membrane by its N-terminus (Abrescia et al., 2004 and Benson et al., 1999). Both N- and C-termini are located outwards from the trimeric protein capsomer, nevertheless they have roles in locking trimers together to form larger capsid facets (Abrescia et al., 2004). The membrane connection might partly explain the observed differences in the localization of P3 fusion proteins. In addition, the loci of eYFP-P3 were occasionally in shuffling motion (data not shown).

These observations indicated that the viral proteins had a specific intracellular distribution and the multimeric ones seemed to accumulate into polar areas of the host cells similarly with bacterial proteins, for example the chemotaxis protein CheA (Sourjik and Berg, 2000) and chaperon protein GroES (Li and Young, 2012) (Fig. 3, Supplementary Fig. S1). However, there were differences in the number of loci between viral proteins thus the process leading to localization might not be the same for all proteins. The specific polar regions for protein localization might be the assembly sites of protein multimers. It has also been reported that the protein aggregation has led to a similar polar localization (Lindner et al., 2008 and Lloyd-Price et al., 2012). However, the low copy-number plasmid pSU18 used here has been widely utilized for the production of functional PRD1 structural 
proteins (Bamford and Bamford, 2000, Bartolome et al., 1991 and Rydman et al., 2001). In addition, the fluorescent fusion proteins of P5 and P31 complemented the defect of virus mutants (Table 2). Also the detected localization varied between proteins and for example the clear difference between monomeric and multimeric proteins indicates that the proteins were produced as soluble (Fig. 2).

\subsection{Proteins P5 and P31 co-localize within a specific locus area}

The observed protein localization was studied further with proteins P5 and P31. In the virion, P5 and P31 are known to interact as a part of the spike vertex complex (Caldentey et al., 2000). To find out whether the proteins co-localize in the same locus, P5 and P31 were fused with eCFP and eYFP, respectively, and their co-expression was imaged by confocal microscopy. The background was manually removed, yielding images only from the higher intensity loci. The loci were considered to be co-localized if the locus emission had contribution from both eCFP and eYFP labels. When P5-eCFP and eYFP-P31 were coproduced, $66 \%$ of the loci were identical $(n=140 / 211)$. Rest of the loci contained only either eYFP-P31 $(16 \%, \mathrm{n}=34 / 211)$ or P5-eCFP $(18 \%, \mathrm{n}=37 / 211)$, which is mostly explained by a production of only one type of fusion protein in a cell.

Based on PRD1 structural data the theoretical maximum distance observed in the virion between the C-terminus of P5 and the N-terminus of P31 is around $30 \mathrm{~nm}$ (Abrescia et al., 2004 and Huiskonen et al., 2007). Protein P5 is an elongated and flexible trimer with a collagen like region in the middle of the protein (Bamford et al., 1991, Bamford and Bamford, 2000, Caldentey et al., 2000 and Sokolova et al., 2001). In addition, the glycine linker region in the fusion protein also allows the fluorescent protein tag to move and interact suggesting that protein-protein interaction could be followed by förster resonance energy transfer (FRET).

We tested the energy transfer between proteins P5 and P31 by fluorescence lifetime microscope (FLIM) measurements using three samples: (i) co-expression of P5-eCFP and eYFP-P31, which represents the ideal combination for the interaction studies, (ii) coexpression of eYFP-P5 and P31-eCFP, where the fluorescent proteins hinder the interaction, and (iii) expression of P31-eCFP, used as a control to observe the lifetime of eCFP in the absence of FRET. With samples (i) and (iii) the lifetime of eCFP was measured from locus area, outside the locus area and from entire cell (Supplementary Fig. S1A). For sample (ii) only entire cells were measured. The results showed a minimal energy transfer in the locus area of sample (i) comparing to other measured samples, and so no significant FRET could be observed (Supplementary Fig. S1B and C). Similar results were obtained when fluorescence spectra and decays were measured by confocal microscopy and timecorrelated single photon counting (TCSPC) from liquid cell samples, respectively (Supplementary Fig. S1D and E). In studies by others (Onuki et al., 2002) the efficiency of the energy transfer between CFP and YFP has been observed to be significantly more efficient than we observed here, although the orientation of P5 and P31 as fusion proteins was theoretically ideal for detection FRET based on their X-ray structures and orientation in the virion. 


\section{Conclusions}

Numerous bacterial proteins and functions have been localized to the poles of bacteria (Gestwicki et al., 2000, Li and Young, 2012 and Maddock et al., 1993) and in other specific regions (Maier et al., 2008, Nevo-Dinur et al., 2012 and Russell and Keiler, 2008). The current knowledge of the complexity of bacterial cells provides also a new aspect to the study of functions and life cycle of bacterial viruses. Animal viruses exploit the organization of host cells in very efficient way and it is likely that bacteriophages do the same. We designed and created a vector library (Fig. 1) and utilized it in expression of virus specific proteins, but the approach can be used easily for other research frames to produce proteins with fluorescent tags. We observed mainly polar localization of several PRD1 viral proteins (Fig. 3). The clear localization was observed only with multimeric proteins as monomeric proteins seemed to be evenly distributed. We also showed that the host receptor recognition vertex associated proteins, the spike protein P5 and the penton protein P31 co-localize within specific cell areas in E. coli. These polar areas might play a role in the multimerization and formation of viral protein complexes.

During the virus life cycle, viral proteins are expressed and function according to precise scheme in a close interaction with each other. When a single viral protein is produced from a plasmid, the protein loses these interactions occurring during the viral replication cycle and this might have an influence on the protein functions. However, in the absence of the natural virus infection context viral proteins tested here showed a clear polarized localization in the host cells. The specific localization pattern of these virus proteins suggests that localization is determined either by the proteins themselves and/or by their interactions with other proteins. This indicates that viral proteins are not randomly distributed in the host cell and their (polar) localization might be explained by interaction with specific bacterial proteins. Based on our results, we suggest that viral proteins are interacting with specific bacterial proteins essential for the viral infection. However, many fundamental aspects regarding the molecular mechanisms of interactions as well as the specific bacterial interactions partners remain to be elucidated.

\section{Materials and methods}

\subsection{Bacteria, plasmids, molecular cloning and protein expression}

The strains and plasmids used in this study are listed in Table 1. Cells were grown on Luria-Bertani (LB) medium with chloramphenicol $(25 \mu \mathrm{g} / \mathrm{ml})$ and kanamycin $(25 \mu \mathrm{g} / \mathrm{ml})$ when appropriate. E. coli HB101 was used as a host for plasmid propagation and molecular cloning. Genes egfp, eyfp and ecfp were amplified by PCR using pEGFP-N3, pECFP-N3 and pEYFP-N3 as templates with primers including a ribosomal binding site (RBS) and restriction enzyme cleavage sites. The fragments were cloned between EcoRI and HindIII restriction sites in pSU18 and pET24 vectors. Site-directed mutagenesis was used to insert a linker encoding six glycines and new restriction enzyme cutting sites in one end of fluorescent protein genes resulting in 12 new vectors (Fig. 1; Table 1). These vectors were used to construct plasmids for production of C-and N-terminal fusions with yellow or cyan fluorescent proteins. For fusion construction PRD1 genes II, III, V, XVI, XVII and XXXI were amplified by PCR using the phage genome as a template and specific 
primers, containing restriction enzyme cutting sites and when needed RBS. The fragments were cloned between $\mathrm{XbaI}$ and $\mathrm{BamHI}$ restriction sites in pKM41, pJK24, pKM54 or pKM64 ( Fig. 1; Table 1). The plasmids were sequenced using the Sanger sequencing method with an automatic sequencer (Applied Biosystems 3130xl Genetic Analyzer) and a BigDye Terminator, version 3.1, Cycle Sequencing Kit (Applied Biosystems). Base calling and sequence refining were performed with Sequencing Analysis, version 5.2.0 (Applied Biosystems). Plasmids were transformed to E. coli HMS174(DE3) cells, which were used for protein expression.

The cells were grown at $28{ }^{\circ} \mathrm{C}$. The protein production was induced at $\mathrm{A} 550=0.75$ by adding isopropyl $\beta$-d-1-thiogalactopyranoside (IPTG, final concentration of $1 \mathrm{mM}$ ) and the growth was continued for $16-20 \mathrm{~h}$ at $18{ }^{\circ} \mathrm{C}$. The strains used for the co-expression of P5eCFP and eYFP-P31 and for co-expression of eYFP-P5 and P31-eCFP were HMS174(DE3)(pSSM21)(pSSM22) and HMS174(DE3)(pJK10)(pJK12), respectively.

\subsection{Solubility and multimericity of the proteins}

Cells were grown as described above and concentrated 1:100 by centrifugation (Sorvall SLA3000, $4200 \mathrm{~g}, 10 \mathrm{~min}, 5^{\circ} \mathrm{C}$ ) in $50 \mathrm{mM}$ Tris-HCl, pH 7.2. Cells were disrupted by a French pressure cell. To analyze the solubility of the proteins, the protein ratio between the supernatant and pellet was determined after centrifugation (Sorvall SLA3000 rotor, 10,800 $\mathrm{g}, 15 \mathrm{~min}, 5^{\circ} \mathrm{C}$ ) by SDS-PAGE and Western blotting. SDS-PAGE was performed according to previously reported method (Olkkonen and Bamford, 1989) and for Western blotting the proteins were transferred onto a PVDF membrane (Millipore). Monoclonal 16A201 (anti-P16) serum (Hänninen et al., 1997) polyclonal antisera agaist PRD1 proteins P2, P3, P5 and P31 antisera (Grahn et al., 1999, Hänninen et al., 1997, Rydman et al., 1999 and Rydman et al., 2001) or anti-GFP (Invitrogen) were used as primary antibodies. Proteins were visualized with the Thermo Scientific Supersignal West Pico Chemiluminescent Substrate kit using HRP-conjugated swine anti-rabbit Igs (Dako) as a secondary antibody.

For the protein multimericity assay the supernatant was applied on a top of a $10-40 \%$ $(\mathrm{w} / \mathrm{v})$ linear sucrose gradient in $50 \mathrm{mM}$ Tris- $\mathrm{HCl}, \mathrm{pH} 7.2$ and centrifuged (Beckmann SW41 rotor, $\left.210,000 \times \mathrm{g}, 42 \mathrm{~h}, 15^{\circ} \mathrm{C}\right)$. Lysozyme $(14.3 \mathrm{kDa})$, albumin $(66 \mathrm{kDa})$, bovine serum albumin $(68 \mathrm{kDa})$, lactate dehydrogenase $(140 \mathrm{kDa})$, aldolase $(158 \mathrm{kDa})$, catalase (232 kDa), ferritin (440 kDa) and thyroglobulin (669 kDa) were used as molecular mass markers. After centrifugation twelve $1 \mathrm{ml}$-fractions and the pellet were collected and analyzed by SDS-PAGE and Western blotting (see above).

PRD1 mutants sus690 (amber mutation in gene $V$ ) and sus525 (amber mutation in gene XXXI) were propagated on Salmonella enterica suppressor strain PSA (supE) or DB7156 (supF30) harboring pLM2, respectively (Table 1). The titers of the viruses were determined on their suppressor strain and on the non-suppressing strain S. enterica serovar Typhimurium LT2 DS88 (wt host; Table 1). The functions of the fluorescent fusion proteins (eYFP-P5, P5-eYFP, P31-eYFP and eYFP-P31) were tested with the mutant viruses by in vivo complementation assay using plasmids carrying either the genes for the fusion proteins or the corresponding PRD1 wt genes $V$ and XXXI ( Table 1). The PRD1 sensitive strain carrying only the cloning vector was used as a negative control. 


\subsection{Confocal microscopy and localization}

The cells were grown as described and diluted 1:1 in phosphate-buffered saline buffer (PBS). Plates were coated with poly-l-lysine (0.01\%, MW 70,000-150,000) and cell suspension was applied to the plates and incubated for 10-20 min. Excess of cell suspension was removed. The samples were covered with LB-soft-agar and imaged immediately.

The imaging was performed with an Olympus FV1000 laser scanning confocal microscope attached to an IX81 inverted microscope frame (Olympus, Japan) with an UPLSAPO 60x water immersion objective having a numerical aperture (NA) 1.20 for live samples or UPLSAPO $60 \times$ oil immersion objective $(\mathrm{NA}=1.3)$ for fixed samples. eGFP was excited with $488 \mathrm{~nm}$ laserline, eCFP with the $405 \mathrm{~nm}$ laserline, and eYFP with $515 \mathrm{~nm}$ laserline, and the fluorescence signals were collected with 500-600 nm, 425-525 nm, and 530-630 $\mathrm{nm}$ band-pass filters, respectively. In co-localization imaging $458 \mathrm{~nm}$ laserline was used for eCFP excitation and the fluorescence was collected with 465-505 nm band-pass filter. Images were captured with an image size of 512 pixels $\times 512$ pixels. For presentation purpose (Fig. 3) the images were cropped further to the size of $18 \mu \mathrm{m} \times 18 \mu \mathrm{m}$. The number of cells with localization loci and the average amount of loci in one cell were calculated from the images from three separate cultivations.

\section{Acknowledgements}

We thank Kati Mökkönen for the help in DNA cloning and Dr. Vladimir Chukharev for technical support. This study was supported by the Academy of Finland Centre of Excellence Program in Virus Research (11296841, 2006-2011 J.K.H.B.), the Centre of Excellence Program in Biological Interactions (252411, 2012-2014 J.K.H.B.), Academy of Finland grants 127665 (H.M.O.), 138063 (J.A.I.) and 251106 (J.K.H.B.) and a grant from the Finnish Cultural Foundation (S.M.). 


\section{References}

Abrescia, N.G., Bamford, D.H., Grimes, J.M., Stuart, D.I., 2012. Structure unifies the viral universe. Annu. Rev. Biochem. 81, 795-822.

Abrescia, N.G., Cockburn, J.J., Grimes, J.M., Sutton, G.C., Diprose, J.M., Butcher, S.J., Fuller, S.D., San Martin, C., Burnett, R.M., Stuart, D.I., Bamford, D.H., Bamford, J.K., 2004. Insights into assembly from structural analysis of bacteriophage PRD1. Nature $432,68-74$.

Amster-Choder, O., 2011. The compartmentalized vessel: The bacterial cell as a model for subcellular organization (a tale of two studies). Cell. Logist 1, 77-81.

Bamford, J.K., Bamford, D.H., 1990. Capsomer proteins of bacteriophage PRD1, a bacterial virus with a membrane. Virology 177, 445-451.

Bamford, J.K., Cockburn, J.J., Diprose, J., Grimes, J.M., Sutton, G., Stuart, D.I., Bamford, D.H., 2002. Diffraction quality crystals of PRD1, a 66-MDa dsDNA virus with an internal membrane. J. Struct. Biol. 139, 103-112.

Bamford, J.K., Hänninen, A.L., Pakula, T.M., Ojala, P.M., Kalkkinen, N., Frilander, M., Bamford, D.H., 1991. Genome organization of membrane-containing bacteriophage PRD1. Virology 183, 658-676.

Bamford, J.K.H., Bamford, D.H., 2000. A new mutant class, made by targeted mutagenesis, of phage PRD1 reveals that protein P5 connects the receptor binding protein to the vertex. J. Virol. 74, 7781-7786.

Bartolome, B., Jubete, Y., Martinez, E., de la Cruz, F., 1991. Construction and properties of a family of pACYC184-derived cloning vectors compatible with pBR322 and its derivatives. Gene 102, 75-78.

Benson, S.D., Bamford, J.K., Bamford, D.H., Burnett, R.M., 1999. Viral evolution revealed by bacteriophage PRD1 and human adenovirus coat protein structures. Cell 98, 825833.

Caldentey, J., Hänninen, A.L., Holopainen, J.M., Bamford, J.K., Kinnunen, P.K., Bamford, D.H., 1999. Purification and characterization of the assembly factor P17 of the lipidcontaining bacteriophage PRD1. Eur. J. Biochem. 260, 549-558.

Caldentey, J., Tuma, R., Bamford, D.H., 2000. Assembly of bacteriophage PRD1 spike complex: role of the multidomain protein P5. Biochemistry 39, 10566-10573.

Chen, I., Christie, P.J., Dubnau, D., 2005. The ins and outs of DNA transfer in bacteria. Science 310, 1456-1460. 
Cockburn, J.J., Abrescia, N.G., Grimes, J.M., Sutton, G.C., Diprose, J.M., Benevides, J.M., Thomas, G.J.,Jr, Bamford, J.K., Bamford, D.H., Stuart, D.I., 2004. Membrane structure and interactions with protein and DNA in bacteriophage PRD1. Nature 432, 122-125.

Deich, J., Judd, E.M., McAdams, H.H., Moerner, W.E., 2004. Visualization of the movement of single histidine kinase molecules in live Caulobacter cells. Proc. Natl. Acad. Sci. U. S. A. 101, 15921-15926.

Edgar, R., Rokney, A., Feeney, M., Semsey, S., Kessel, M., Goldberg, M.B., Adhya, S., Oppenheim, A.B., 2008. Bacteriophage infection is targeted to cellular poles. Mol. Microbiol. 68, 1107-1116.

Gerdes, K., Howard, M., Szardenings, F., 2010. Pushing and pulling in prokaryotic DNA segregation. Cell 141, 927-942.

Gestwicki, J.E., Lamanna, A.C., Harshey, R.M., McCarter, L.L., Kiessling, L.L., Adler, J., 2000. Evolutionary conservation of methyl-accepting chemotaxis protein location in Bacteria and Archaea. J. Bacteriol. 182, 6499-6502.

Grahn AM, Butcher SJ, Bamford JKH, Bamford DH., 2006. PRD1 - dissecting the genome, structure and entry. In: Calendar R. (Ed.), The Bacteriophages. Oxford University Press, New York, pp. 161-170.

Grahn, A.M., Caldentey, J., Bamford, J.K., Bamford, D.H., 1999. Stable packaging of phage PRD1 DNA requires adsorption protein P2, which binds to the IncP plasmid-encoded conjugative transfer complex. J. Bacteriol. 181, 6689-6696.

Hänninen, A.L., Bamford, D.H., Bamford, J.K., 1997. Probing phage PRD1-specific proteins with monoclonal and polyclonal antibodies. Virology 227, 198-206.

Hellwig, D., Münch, S., Orthaus, S., Hoischen, C., Hemmerich, P., Diekmann, S., 2008. Live-cell imaging reveals sustained centromere binding of CENP-T via CENP-A and CENP-B. J. Biophotonics 1, 245-254.

Holopainen, J.M., Saily, M., Caldentey, J., Kinnunen, P.K., 2000. The assembly factor P17 from bacteriophage PRD1 interacts with positively charged lipid membranes. Eur. J. Biochem. 267, 6231-6238.

Huiskonen, J.T., Manole, V., Butcher, S.J., 2007. Tale of two spikes in bacteriophage PRD1. Proc. Natl. Acad. Sci. U. S. A. 104, 6666-6671.

Jaatinen, S.T., Viitanen, S.J., Bamford, D.H., Bamford, J.K., 2004. Integral membrane protein P16 of bacteriophage PRD1 stabilizes the adsorption vertex structure. J. Virol. 78, 9790-9797.

Jakutyte, L., Baptista, C., Sao-Jose, C., Daugelavicius, R., Carballido-Lopez, R., Tavares, P., 2011. Bacteriophage infection in rod-shaped gram-positive bacteria: evidence for a 
preferential polar route for phage SPP1 entry in Bacillus subtilis. J. Bacteriol. 193, 48934903.

Khayat, R., Tang, L., Larson, E.T., Lawrence, C.M., Young, M., Johnson, J.E., 2005. Structure of an archaeal virus capsid protein reveals a common ancestry to eukaryotic and bacterial viruses. Proc. Natl. Acad. Sci. U. S. A. 102, 18944-18949.

Lai, E.M., Nair, U., Phadke, N.D., Maddock, J.R., 2004. Proteomic screening and identification of differentially distributed membrane proteins in Escherichia coli. Mol. Microbiol. 52, 1029-1044.

Leonardy, S., Miertzschke, M., Bulyha, I., Sperling, E., Wittinghofer, A., SogaardAndersen, L., 2010. Regulation of dynamic polarity switching in bacteria by a Ras-like G-protein and its cognate GAP. EMBO J. 29, 2276-2289.

Lindner, A.B., Madden, R., Demarez, A., Stewart, E.J., Taddei, F., 2008. Asymmetric segregation of protein aggregates is associated with cellular aging and rejuvenation. Proc. Natl. Acad. Sci. U. S. A. 105, 3076-3081.

Lloyd-Price, J., Häkkinen, A., Kandhavelu, M., Marques, I.J., Chowdhury, S., Lihavainen, E., Yli-Harja, O., Ribeiro, A.S., 2012. Asymmetric disposal of individual protein aggregates in Escherichia coli, one aggregate at a time. J. Bacteriol. 194, 1747-1752.

Li, G., Young, K.D., 2012. Isolation and identification of new inner membrane-associated proteins that localize to cell poles in Escherichia coli. Mol. Microbiol. 84, 276-295.

Loose, M., Kruse, K., Schwille, P., 2011. Protein self-organization: lessons from the min system. Annu. Rev. Biophys. 40, 315-336.

Maddock, J.R., Alley, M.R., Shapiro, L., 1993. Polarized cells, polar actions. J. Bacteriol. 175, 7125-7129.

Maier, K.S., Hubich, S., Liebhart, H., Krauss, S., Kuhn, A., Facey, S.J., 2008. An amphiphilic region in the cytoplasmic domain of $\mathrm{KdpD}$ is recognized by the signal recognition particle and targeted to the Escherichia coli membrane. Mol. Microbiol. 68, 1471-1484.

Merckel, M.C., Huiskonen, J.T., Bamford, D.H., Goldman, A., Tuma, R., 2005. The structure of the bacteriophage PRD1 spike sheds light on the evolution of viral capsid architecture. Mol. Cell 18, 161-170.

Mindich, L., Cohen, J., Weisburd, M., 1976. Isolation of nonsense suppressor mutants in Pseudomonas. J. Bacteriol. 126, 177-182.

Mindich, L., Bamford, D., McGraw, T., Mackenzie, G., 1982. Assembly of bacteriophage PRD1: particle formation with wild-type and mutant viruses. J. Virol. 44, 1021-1030. 
Muñoz-Espín, D., Daniel, R., Kawai, Y., Carballido-Lopez, R., Castilla-Llorente, V., Errington, J., Meijer, W.J., Salas, M., 2009. The actin-like MreB cytoskeleton organizes viral DNA replication in bacteria. Proc. Natl. Acad. Sci. U. S. A.

Muñoz-Espín, D., Holguera, I., Ballesteros-Plaza, D., Carballido-Lopez, R., Salas, M., 2010. Viral terminal protein directs early organization of phage DNA replication at the bacterial nucleoid. Proc. Natl. Acad. Sci. U. S. A. 107, 16548-16553.

Nandhagopal, N., Simpson, A.A., Gurnon, J.R., Yan, X., Baker, T.S., Graves, M.V., Van Etten, J.L., Rossmann, M.G., 2002. The structure and evolution of the major capsid protein of a large, lipid-containing DNA virus. Proc. Natl. Acad. Sci. U. S. A. 99, 1475814763.

Nevo-Dinur, K., Govindarajan, S., Amster-Choder, O., 2012. Subcellular localization of RNA and proteins in prokaryotes. Trends Genet. 28, 314-322.

Nevo-Dinur, K., Nussbaum-Shochat, A., Ben-Yehuda, S., Amster-Choder, O., 2011. Translation-independent localization of mRNA in E. coli. Science 331, 1081-1084.

Oksanen H.M., Bamford D.H., 2012. Family Tectiviridae, in: King A.M.Q., Adams M.J., Carstens E.B., Lefkowitz E.J. (Eds.), Virus taxonomy, Ninth Report of the International Committee on Taxonomy of Viruses. Elsevier, Oxford, pp 317-322.

Olsen, R.H., Siak, J.S., Gray, R.H., 1974. Characteristics of PRD1, a plasmid-dependent broad host range DNA bacteriophage. J. Virol. 14, 689-699.

Onuki, R., Nagasaki, A., Kawasaki, H., Baba, T., Uyeda, T.Q., Taira, K., 2002. Confirmation by FRET in individual living cells of the absence of significant amyloid beta -mediated caspase 8 activation. Proc. Natl. Acad. Sci. U. S. A. 99, 14716-14721.

Ramamurthi, K.S., 2010. Protein localization by recognition of membrane curvature. Curr. Opin. Microbiol. 13, 753-757.

Redrejo-Rodriguez, M., Muñoz-Espín, D., Holguera, I., Mencia, M., Salas, M., 2012. Functional eukaryotic nuclear localization signals are widespread in terminal proteins of bacteriophages. Proc. Natl. Acad. Sci. U. S. A. 109, 18482-18487.

Rothenberg, E., Sepúlveda, L.A., Skinner, S.O., Zeng, L., Selvin, P.R., Golding, I., 2011. Single-virus tracking reveals a spatial receptor-dependent search mechanism. Biophys. J. 100, 2875-2882.

Rudner, D.Z., Losick, R., 2002. A sporulation membrane protein tethers the pro-sigmaK processing enzyme to its inhibitor and dictates its subcellular localization. Genes Dev. 16, 1007-1018.

Rudner, D.Z., Losick, R., 2010. Protein subcellular localization in bacteria. Cold Spring Harb Perspect. Biol. 2, a000307. 
Russell, J.H., Keiler, K.C., 2007. Peptide signals encode protein localization. J. Bacteriol. 189, 7581-7585.

Russell, J.H., Keiler, K.C., 2008. Screen for localized proteins in Caulobacter crescentus. PLoS One 3, e1756.

Rydman, P.S., Bamford, J.K., Bamford, D.H., 2001. A minor capsid protein P30 is essential for bacteriophage PRD1 capsid assembly. J. Mol. Biol. 313, 785-795.

Rydman, P.S., Caldentey, J., Butcher, S.J., Fuller, S.D., Rutten, T., Bamford, D.H., 1999. Bacteriophage PRD1 contains a labile receptor-binding structure at each vertex. J. Mol. Biol. 291, 575-587.

Saren, A.M., Ravantti, J.J., Benson, S.D., Burnett, R.M., Paulin, L., Bamford, D.H., Bamford, J.K., 2005. A snapshot of viral evolution from genome analysis of the Tectiviridae family. J. Mol. Biol. 350, 427-440.

Shimozono, S., Hosoi, H., Mizuno, H., Fukano, T., Tahara, T., Miyawaki, A., 2006. Concatenation of cyan and yellow fluorescent proteins for efficient resonance energy transfer. Biochemistry 45, 6267-6271.

Sokolova, A., Malfois, M., Caldentey, J., Svergun, D.I., Koch, M.H., Bamford, D.H., Tuma, R., 2001. Solution structure of bacteriophage PRD1 vertex complex. J. Biol. Chem. 276, 46187-46195.

Sourjik, V., Berg, H.C., 2000. Localization of components of the chemotaxis machinery of Escherichia coli using fluorescent protein fusions. Mol. Microbiol. 37, 740-751.

Swulius, M.T., Jensen, G.J., 2012. The helical MreB cytoskeleton in Escherichia coli MC1000/pLE7 is an artifact of the N-Terminal yellow fluorescent protein tag. J. Bacteriol. 194, 6382-6386.

Tkachenko, N.V., 2006. Optical Spectroscopy: Methods and Instrumentations. Elsevier, Amsterdam, pp. 115.

Tramier, M., Gautier, I., Piolot, T., Ravalet, S., Kemnitz, K., Coppey, J., Durieux, C., Mignotte, V., Coppey-Moisan, M., 2002. Picosecond-hetero-FRET microscopy to probe protein-protein interactions in live cells. Biophys. J. 83, 3570-3577.

Vats, P., Yu, J., Rothfield, L., 2009. The dynamic nature of the bacterial cytoskeleton. Cell Mol. Life Sci. 66, 3353-3362.

Winston, F., Botstein, D., Miller, J.H., 1979. Characterization of amber and ochre suppressors in Salmonella typhimurium. J. Bacteriol. 137, 433-439. 
Xu, L., Benson, S.D., Butcher, S.J., Bamford, D.H., Burnett, R.M., 2003. The receptor binding protein $\mathrm{P} 2$ of PRD1, a virus targeting antibiotic-resistant bacteria, has a novel fold suggesting multiple functions. Structure 11, 309-322. 


\section{Figures and Tables}
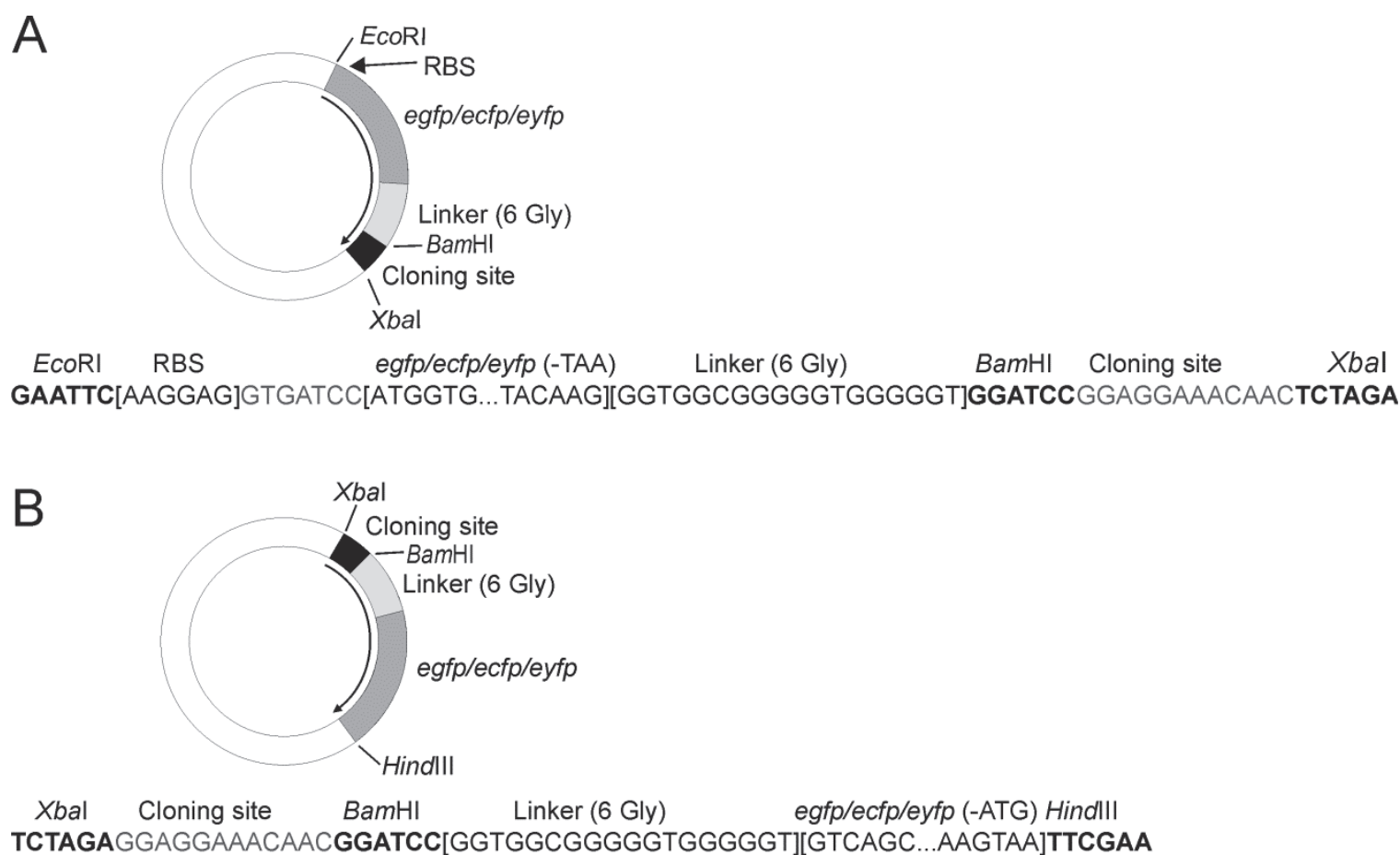

Fig. 1. Vector library. Vectors and sequence of mutated area shown by arrow for production of fluorescent fusion proteins. (A) Vectors for production of N-terminal fusion proteins containing egfp (pKM57 and pJK22), ecfp (pKM51 and pJK24) or eyfp (pKM54 and pJK28). Genes for fluorescent proteins are indicated by dark gray. The cloning site (BamHI-XbaI) and the glysine linker are shown by black and light gray, respectively. (B) Vectors for C-terminal fusion proteins containing egfp (pKM47 and pKM67), ecfp (pKM41 and pKM61) or eyfp (pKM44 and pKM64). Colors are like in (A). See also Table 1. 


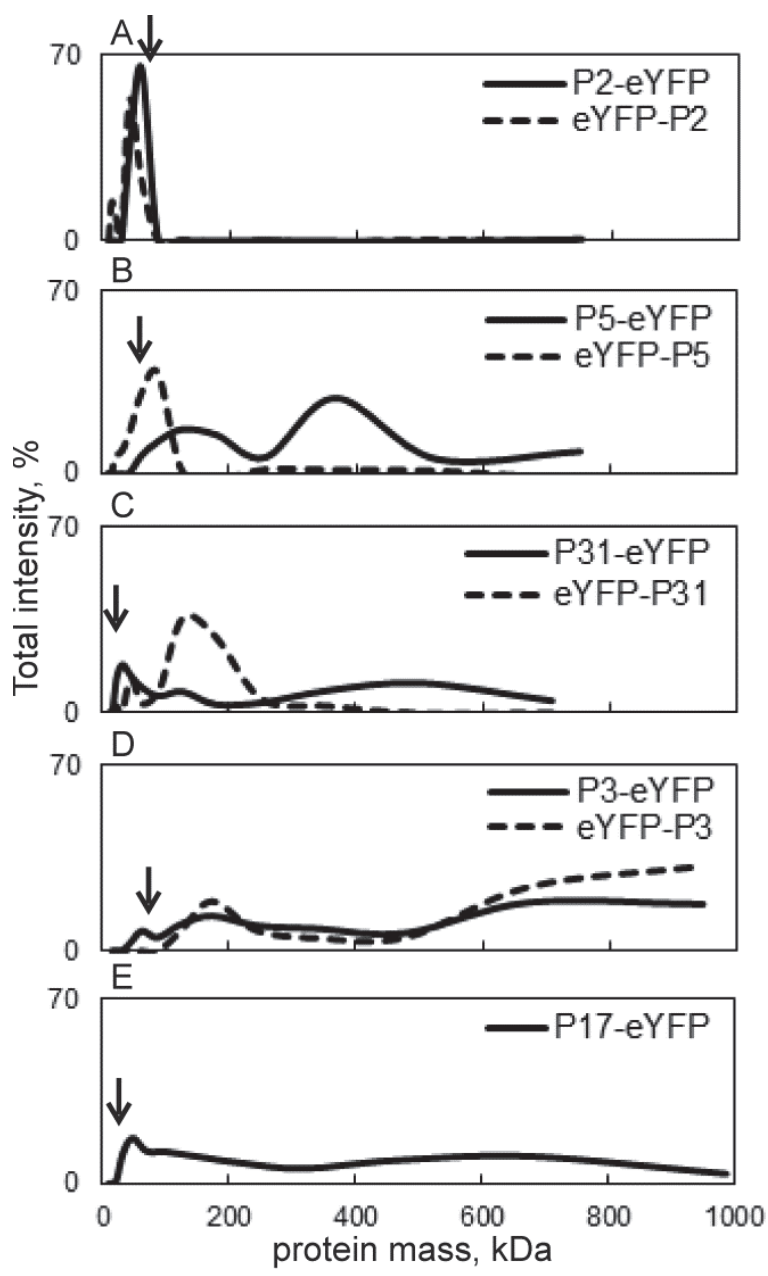

Fig. 2. Sedimentation assay to determine the multimericity of the fluorescent fusion proteins. The masses of the expressed proteins from the soluble fraction of the cell extracts were analyzed by rate zonal centrifugation using standard proteins as a control (see Section 4), SDS-PAGE and Western blotting using specific antibodies against P2, P5, P31 and P3. The P17 fusion protein was identified with antibody against GFP. Calculated monomeric masses are shown by arrows. Only fusion proteins with correct monomeric molecular mass were taken account when creating the image, smaller side products were seen with proteins P5 and P2. (A) Receptor binding protein P2 (monomeric in the virion). (B) Spike protein P5 (trimeric in the virion). (C) Penton protein P31 (pentameric in the virion). (D) Major capsid protein P3 (trimer in the virion). (E) Assembly factor P17 (tetrameric in its native form). 
P16, vertex stabilizing membrane protein
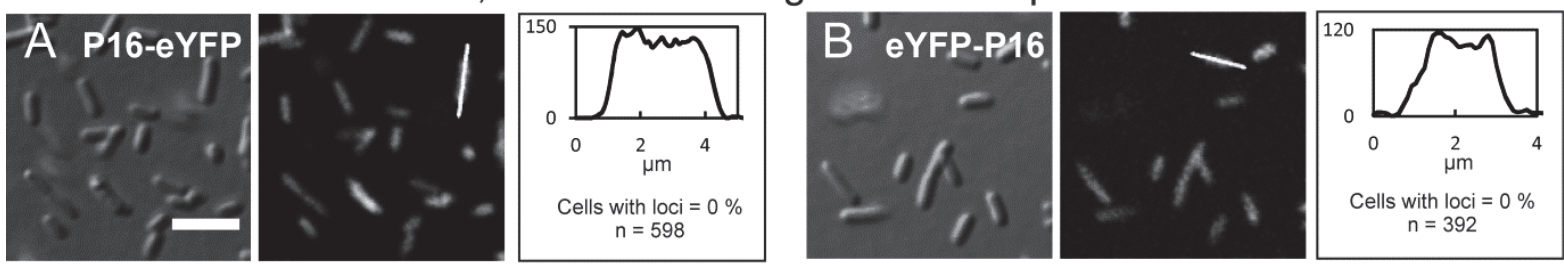

P2, monomeric receptor binding protein
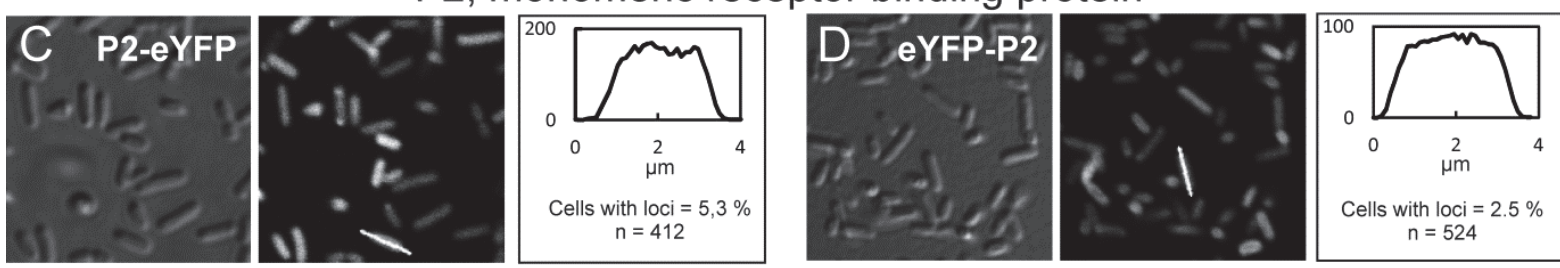

\section{$\mathrm{P} 5$, trimeric spike protein}
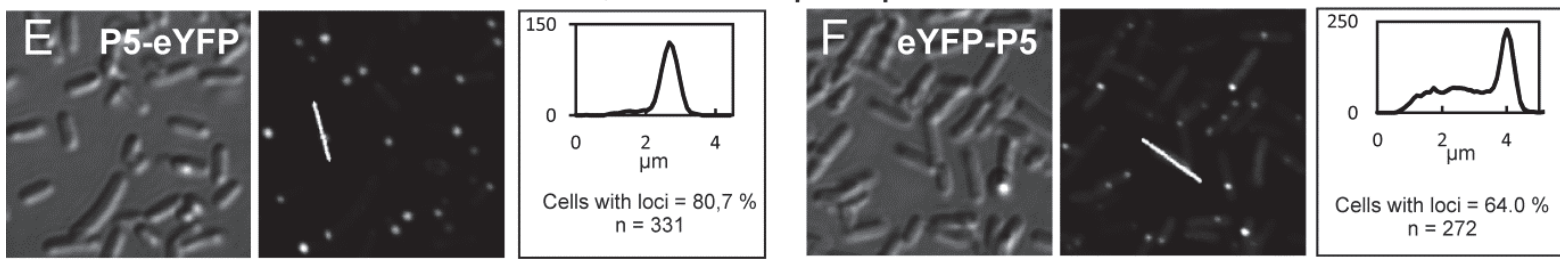

P31, pentameric penton protein
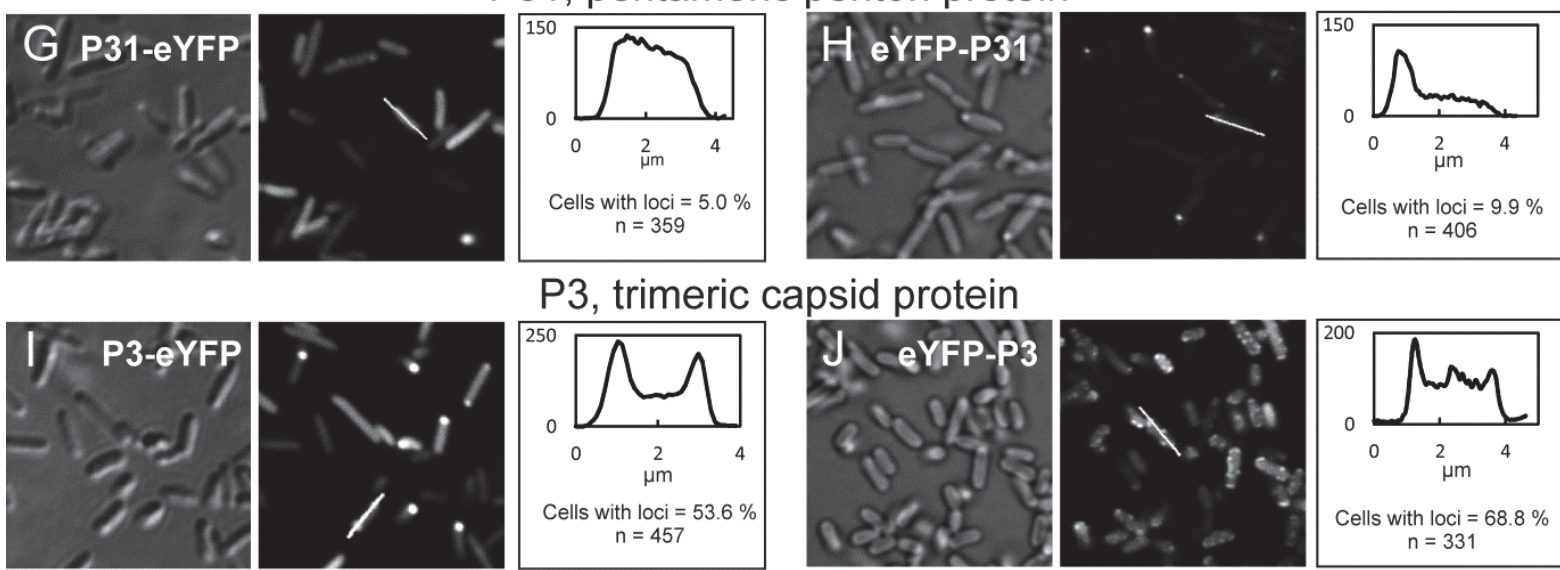

$\mathrm{P} 3$, trimeric capsid protein
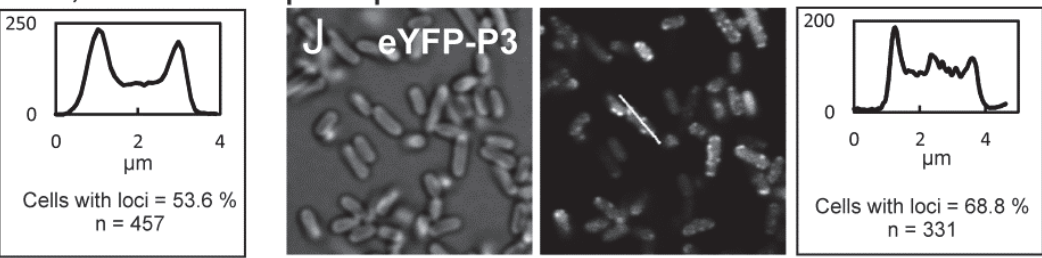

$\mathrm{P} 17$, tetrameric assembly protein
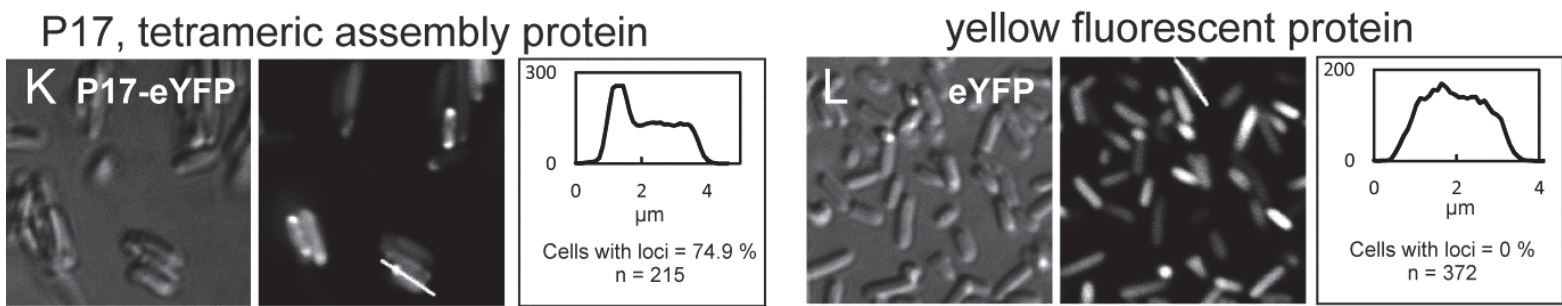

Fig. 3. Localization of PRD1 proteins. Confocal microscope images of different fluorescent fusion proteins of PRD1 overproduced in E. coli HMS174 (DE3) cells. In the left column differential interference contrast (DIC) image, in the middle fluorescence image and on the right intensity (y axes) profile of a single cell marked with a white line (see the fluorescence image) and percentage of cells with loci are shown. The scale bar applicable to all images in $(A)$ is $5 \mu \mathrm{m}$. 


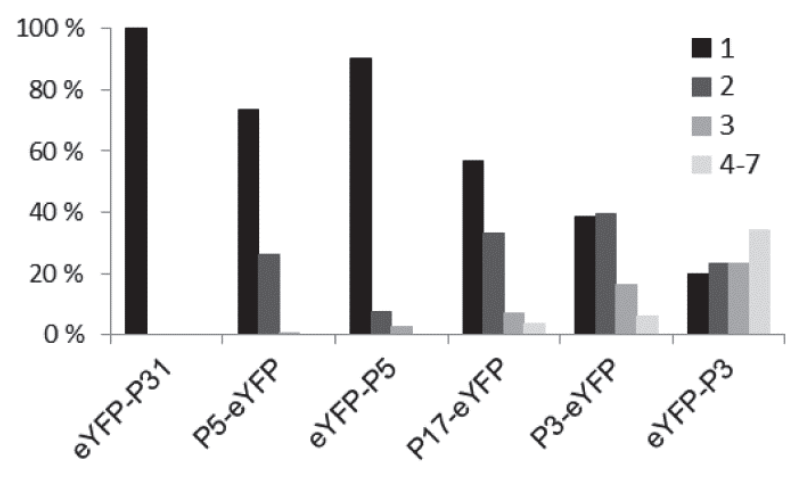

Fig. 4. Amount of loci in single cells. The distribution of amount of loci in one cell calculated from images used in Fig. 3. Only cells with loci were taken account. 
Table 1. Phages, bacterial strains and plasmids used in this study

\begin{tabular}{|c|c|c|c|}
\hline $\begin{array}{l}\text { Phages, } \\
\text { bacterial strains } \\
\text { and plasmids }\end{array}$ & $\begin{array}{l}\text { Relevant genotype or Description (nt coordinates in } \\
\text { PRD1 genome) }^{a}\end{array}$ & $\begin{array}{l}\text { Relevant } \\
\text { phenotype }\end{array}$ & $\begin{array}{l}\text { Source or } \\
\text { reference }\end{array}$ \\
\hline \multicolumn{4}{|l|}{ Phages } \\
\hline PRD1 wt & & & $\begin{array}{l}\text { Olsen et } \\
\text { al., } 1974\end{array}$ \\
\hline sus690 PRD1 & Amber mutation in gene $V$ & & $\begin{array}{ll} & \text { Bamford } \\
\text { and } & \text { Bamford, } \\
2000 & \\
\end{array}$ \\
\hline sus525 & Amber mutation in gene $X X X I$ & & $\begin{array}{l}\text { Rydman } \\
\text { et al., } 1999\end{array}$ \\
\hline \multicolumn{4}{|l|}{$\begin{array}{l}\text { Bacteria } \\
\text { I strains }\end{array}$} \\
\hline \multicolumn{4}{|l|}{$\begin{array}{l}\text { Escheric } \\
\text { hia coli } \mathrm{K}-12\end{array}$} \\
\hline HB101 & $\begin{array}{l}\text { supE44 hsdS20 }\left(\mathrm{r}_{\mathrm{B}}^{-} \mathrm{m}_{\mathrm{B}}\right) \text { recA13 ara14 proA2 lacY1 galK2 } \\
\text { rpsL20 xyl5 } \mathrm{mtl} 1\end{array}$ & Cloning host & $\begin{array}{ll} & \text { Bolivar } \\
\text { and } & \text { Backman, } \\
1979 & \end{array}$ \\
\hline HMS174(DE3) & recA1 hsd $\mathrm{Rf}^{\mathrm{r}}$ & host $\quad$ Expression & $\begin{array}{l}\text { Campbell } \\
\text { et al., } 1978\end{array}$ \\
\hline \multicolumn{4}{|l|}{$\begin{array}{l}\text { Salmone } \\
\text { Ila enterica } \\
\text { serovar } \\
\text { Typhimurium } \\
\text { LT2 }\end{array}$} \\
\hline DS88 & SL5676 $\triangle H 2$ H1-i::Tn 10 (TcS) (pLM2) & $\begin{array}{l}\text { Non- } \\
\text { suppressor host for } \\
\text { PRD1 }\end{array}$ & $\begin{array}{ll} & \text { Bamford } \\
\text { and } & \text { Bamford, } \\
1990 & \\
\end{array}$ \\
\hline $\operatorname{PSA}(p L M 2)$ & supE & $\begin{array}{l}\text { Suppressor } \\
\text { host for sus690 }\end{array}$ & $\begin{array}{l}\text { Mindich } \\
\text { et al., } 1976\end{array}$ \\
\hline DB7156(pLM2) & leuA414(Am) hisC527(Am) supF30 & $\begin{array}{l}\text { Suppressor } \\
\text { host for sus525 }\end{array}$ & $\begin{array}{l}\text { Winston } \\
\text { et al., } 1979\end{array}$ \\
\hline \multicolumn{4}{|l|}{$\mathbf{s}$} \\
\hline pLM2 & & $\begin{array}{l}\text { Encodes } \\
\text { PRD1 receptor }\end{array}$ & $\begin{array}{l}\text { Mindich } \\
\text { et al., } 1976\end{array}$ \\
\hline pSU18 & Low-copy-number cloning vector; $\mathrm{p} 15 \mathrm{~A}$ replicon, $\mathrm{Cm}^{\mathrm{R}}$ & & $\begin{array}{l}\text { Bartolome } \\
\text { et al., } 1991\end{array}$ \\
\hline pET24 & High-level-expression vector; ColE1 replicon, $\mathrm{Km}^{\mathrm{R}}$ & & Novagen \\
\hline pJB500 & pSU18 + PRD1 $X X X I+V$ & P5 and P31 & $\begin{array}{ll} & \text { Bamford } \\
\text { and } & \text { Bamford, } \\
2000 & \\
\end{array}$ \\
\hline pEGFP- & & & Clontech \\
\hline N3 pECFP- & & & Clontech \\
\hline N3 pEYFP- & & & Clontech \\
\hline pJK5 & pSU18 $\Delta($ EcoRI-HindIII $) \Omega(T 7$ RBS + egfp from pEGFP-N3) & eGFP & This study \\
\hline
\end{tabular}




\begin{tabular}{|c|c|c|c|}
\hline pJK6 & pSU18D(EcoRI-HindIII) $\Omega(T 7$ RBS + ecfp from pECFP-N3) & eCFP & This study \\
\hline pJK7 & pSU18D(EcoRI-HindIII) $\Omega($ T7 RBS + eyfp from pEYFP-N3) & eYFP & This study \\
\hline pSSM1 & $\mathrm{pET} 24 \Delta($ EcoRI-HindIII) $\Omega(\mathrm{T} 7 \mathrm{RBS}+$ egfp from pEGFP-N3) & eGFP & This study \\
\hline pSSM2 & $\mathrm{pET} 24 \Delta($ EcoRI-HindIII) $\Omega(\mathrm{T7}$ RBS + ecfp from pECFP-N3) & eCFP & This study \\
\hline pSSM3 & 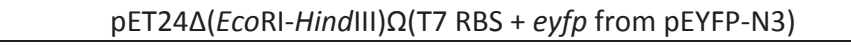 & eYFP & This study \\
\hline pKM57 & pJK5 $\Omega($ BamHI-Xbal) $\Omega(6$ x Gly) & \multirow{12}{*}{$\begin{array}{l}\text { Cloning } \\
\text { vector for fusion } \\
\text { protein production }\end{array}$} & This study \\
\hline pKM51 ${ }^{\mathrm{b}}$ & pJK6 $\Omega($ BamHI-Xbal $) \Omega(6 \times$ Gly $)$ & & This study \\
\hline pKM54 ${ }^{\mathrm{b}}$ & $\mathrm{pJK} 7 \Omega($ BamHI-Xbal) $\Omega(6$ x Gly) & & This study \\
\hline pKM67 ${ }^{b}$ & $\mathrm{pJK} 5 \Omega($ Xbal-BamHI $) \Omega(6 \times$ Gly $) \Delta($ T7 RBS $)$ & & This study \\
\hline pKM61 ${ }^{\mathrm{b}}$ & pJK6 $\Omega($ Xbal-BamHI $) \Omega(6 \times$ Gly $) \Delta($ T7 RBS $)$ & & This study \\
\hline pKM64 ${ }^{\mathrm{b}}$ & $\mathrm{pJK} 7 \Omega($ Xbal-BamHI $) \Omega(6 \times$ Gly $) \Delta(\mathrm{T} 7 \mathrm{RBS})$ & & This study \\
\hline $\mathrm{pJK} 22^{\mathrm{b}}$ & pSSM1 $\Omega($ BamHI-Xbal) $\Omega(6$ x Gly) & & This study \\
\hline $\mathrm{pJK} 24^{\mathrm{b}}$ & pSSM $2 \Omega($ BamHI-Xbal) $\Omega(6$ x Gly) & & This study \\
\hline $\mathrm{pJK} 28^{\mathrm{b}}$ & pSSM $3 \Omega($ BamHI-Xbal) $\Omega(6$ x Gly) & & This study \\
\hline pKM47 & $\operatorname{pSSM} 1 \Omega($ Xbal-BamHI $) \Omega(6 \times$ Gly $) \Delta($ T7 RBS $)$ & & This study \\
\hline pKM41 ${ }^{\text {b }}$ & $\operatorname{pSSM} 2 \Omega($ Xbal-BamHI $) \Omega(6 \times$ Gly $) \Delta($ T7 RBS $)$ & & This study \\
\hline pKM44 ${ }^{\mathrm{b}}$ & $\operatorname{pSSM} 3 \Omega($ Xbal-BamHI) $\Omega(6 \times$ Gly $) \Delta($ T7 RBS $)$ & & This study \\
\hline pSSM22 & pKM41 $($ Xbal-BamHI) $\Omega($ PRD1 gene $V(5287-6309))$ & P5-eCFP & This study \\
\hline pJK8 & 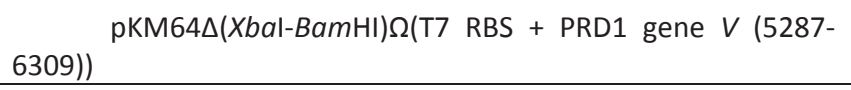 & P5-eYFP & This study \\
\hline pJK10 & pKM54 $($ BamHI-Xbal) $\Omega($ PRD1 gene $V(5287-6309))$ & eYFP-P5 & This study \\
\hline pJK12 & pKM41 $(X b a l-B a m H I) \Omega(P R D 1$ gene $X X X I$ (4907-5287)) & P31-eCFP & This study \\
\hline pSSM20 & 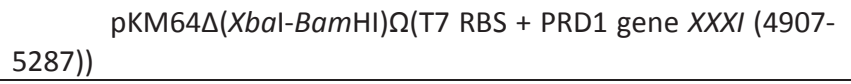 & P31-eYFP & This study \\
\hline pSSM21 & pKM54 $($ BamHI-Xbal) $\Omega($ PRD1 gene $X X X I$ (4907-5287)) & eYFP-P31 & This study \\
\hline pSSM30 & 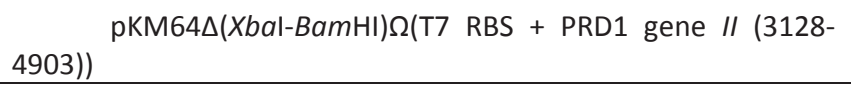 & P2-eYFP & This study \\
\hline pSSM32 & pKM54 $($ BamHI-Xbal) $\Omega($ PRD1 gene II (3128-4903)) & eYFP-P2 & This study \\
\hline pSSM39 & 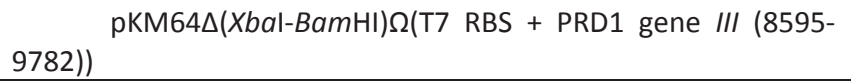 & P3-eYFP & This study \\
\hline pSSM41 & pKM54 $($ BamHI-Xbal) $\Omega($ PRD1 gene III (8595-9782)) & eYFP-P3 & This study \\
\hline pSSM43 & 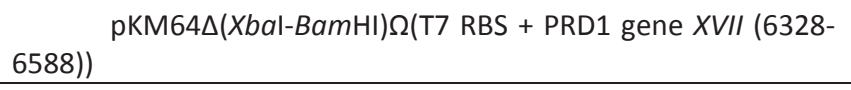 & P17-eYFP & This study \\
\hline pSSM49 & $\begin{array}{l}\text { pKM64 }(\text { Xbal-BamHI) } \Omega(\text { T7 RBS + PRD1 gene XVI (11836- } \\
\text { 12189)) }\end{array}$ & P16 - eYFP & This study \\
\hline pSSM34 & pKM54 $\Delta($ BamHI-Xbal) $\Omega($ PRD1 gene XVI (11836-12189)) & eYFP-P16 & This study \\
\hline
\end{tabular}

a) Gene Bank Acc No AY848689 (Bamford et al., 1991; Saren et al., 2005)

b) See details in Fig. 1. 
Table 2. Complementation titers of PRD1 mutants on strains producing either P5 or P31 fusion proteins

\begin{tabular}{|c|c|c|c|}
\hline \multirow[b]{2}{*}{ Strain } & \multirow[b]{2}{*}{ Description } & \multicolumn{2}{|c|}{ Titers (pfu / ml) } \\
\hline & & $\begin{array}{l}\text { sus690 } \\
\text { (gene } V \\
\text { mutant) }\end{array}$ & $\begin{array}{l}\text { sus525 } \\
\text { (gene XXXI } \\
\text { mutant) }\end{array}$ \\
\hline DS88 & $\begin{array}{c}\text { non- } \\
\text { suppressor host }\end{array}$ & $2 \times 10^{5}$ & $1 \times 10^{5}$ \\
\hline PSA & 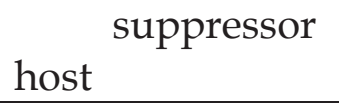 & $3 \times 10^{11}$ & \\
\hline DB7156 & 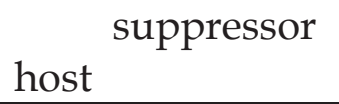 & & $2 \times 10^{11}$ \\
\hline $\begin{array}{ll}\text { HMS174(pLM2)(pS } \\
\text { U18) }\end{array}$ & $\begin{array}{l}\text { negative } \\
\text { control }\end{array}$ & $2.6 \times 10^{4}$ & $3.3 \times 10^{4}$ \\
\hline 500) ${ }$ HMS174(pLM2)(pJB & $\begin{array}{l}\text { positive } \\
\text { control }\end{array}$ & $1 \times 10^{10}$ & $1.6 \times 10^{10}$ \\
\hline K10) & eYFP-P5 & $1 \times 10^{10 a}$ & \\
\hline $\begin{array}{ll} & \mathrm{HMS174}(\mathrm{pLM} 2)(\mathrm{pJ} \\
\mathrm{K} 8) & \end{array}$ & P5-eYFP & $2.3 \times 10^{10}$ & \\
\hline $\begin{array}{l}\text { HMS174(pLM2)(pS } \\
\text { SM20) }\end{array}$ & P31-eYFP & & $2.4 \times 10^{10}$ \\
\hline $\begin{array}{l}\text { HMS174(pLM2)(pS } \\
\text { SM21) }\end{array}$ & eYFP-P31 & & $4.9 \times 10^{10}$ \\
\hline
\end{tabular}

a) A bit weaker plaques than in other plates 